Thus, the supplies of bacon from Commonwealth sources are unlikely to increase as fast as supplies from home production, and supplies from European sources are already increasing. There is, however, one new possibility in the future, the production of pigs as part of the grain-sorghum scheme in Queensland. It is too soon as yet to estimate the potentialities of this scheme, but one word of caution is necessary. Sorghum can be used to replace only such foods as maize in the fattening of pigs. Adequate supplies of protein-containing foods for sows and weaners will, therefore, be the limiting factor in this form of pig production. The success of the scheme will thus depend upon one or both of two factors, the discovery of new supplies of feeding-stuffs containing animal protein, and the more efficient use of present supplies. There is no doubt that feeding-stuffs containing animal protein have been used very wastefully in the past and could be used far more efficiently in the future. The discovery of cheap sources of vitamin $B_{12}$ also would help with the large-scale production of store pigs for fattening on sorghum.

\title{
Commonwealth Contributions and British Requirement of Fruit
}

\author{
By R. G. Tомкіss, Ditton Laboratory, East Malling, Kent
}

The supplies of fruit which have been mentioned in the papers presented to this meeting, and which might be imported into Great Britain include: apples from New Zealand; apples, dried apples, and fruit pulp from Canada; fruit juices, tomato juice, and fruit cakes from Australia; grapes, deciduous fruits, citrus fruits, canned fruit and fruit juices from South Africa (Heywood, 1950; Hopkirk, 1950; Robertson, 1950; van der Post, 1950). Rather than try to comment on the individual items mentioned, it may be best to consider the supplies of fruit which have been available in the past and some of the factors which may affect supplies in the future.

Before the war there were few restrictions to the importation of fruit into Britain, and supplies depended on production overseas, the availability of suitable shipping, and the ease with which fruit could be sold in the wholesale markets. Figures for prewar imports which can be obtained from Fruit or Fruit Supplies compiled by Intelligence Branch, Imperial Economic Committee, and published yearly by H.M. Stationery Office, show the great quantity and variety of fruits which were available throughout the year, mainly because England drew her supplies from all the producing countries of the world and imported $45 \%$ of the total deciduous crop, and $35 \%$ of the total citrus crop, exported from the principal producing countries. During the war imports of fruits were restricted by the lack of suitable shipping and by government regulation, and consumption per head fell from $92 \mathrm{lb}$. in 1939 to 19 in 1941 . The latest figures for the supplies of fruit available in Britain show that there has been a partial return to the prewar pattern of imports but that, whereas in 1936 consumption was $84 \mathrm{lb}$./head, of which only about one-quarter was home grown, in 1947 the corresponding consumption was $76 \mathrm{lb}$., of which about one-half was home grown. 
Some of the more important factors which have affected our supplies are listed below:

(I) In England the supplies of dessert apples are slowly increasing as young trees come into bearing. In 1944 the number of Cox's Orange Pippin trees under 9 years old was 3,012,900, and over 9 years 1,525,000. For Bramley's Seedling the corresponding figures were 291,500 and $1,881,300$.

The present home production of apples, about 400,000 tons, is, however, equal only to about $15 \mathrm{lb}$./head/year, and is insufficient to meet the all-the-year-round demand, though it would be possible to preserve cooking apples such as Bramley's Seedlings from one season to the next if it were necessary. The capacity for cold storage and for gas storage of fruit is about $4,000,000$ cu.ft. or 40,000 tons, and is being rapidly increased. Owners are, however, anxious to consider uses for their stores after they have disposed of their apples. At present, varieties of dessert apples which could be stored beyond January or February are not grown in any quantity in England. It would be possible to meet a demand for late-season dessert apples by growing such varieties as Tydeman's Late Orange, Winston, Barnack Beauty and Belle de Boscoop.

The production of pears also is increasing but that of plums is decreasing somewhat.

The planting of bush fruit was restricted during the war and both acreage and production are lower than in prewar years. It is probable that production may increase somewhat, not so much to meet the demand for fresh fruit as for the production of blackcurrant juice, for jam making and for the frozen-packaged fruit industry.

(2) There have been changes in the supplies of fruit from overseas. The production of bananas in Jamaica has decreased through the reduction in shipments during the war and through losses due to hurricanes, and to Panama and leaf-spot disease. Production in 1947 was only about one-third of prewar. It is probable that supplies will increase but that the Gros Michel variety will be replaced by others which are less susceptible to disease but which may require different conditions when shipped.

Production of oranges in countries normally supplying Great Britain is at present below prewar level. In Palestine some trees were uprooted during the war and the land was used for other crops. In South Africa the demand in the home market is now greater. In Brazil production has decreased through orchard diseases, and Rhodesia now uses most of her production for by-products. There are, however, greater supplies of concentrated orange juice.

(3) There have been no new methods of preserving fruit in the fresh state. Hence, though we could import pine-apples from South Africa, we could not hope to import them from Queensland, or mangoes from India. Two advances should, however, be mentioned. The use of diphenyl wraps and fumigation with nitrogen trichloride has considerably reduced wastage in oranges imported from Palestine, and the use of 'dual temperature shipment', i.e., carriage first at $31^{\circ} \mathrm{F}$. and then at $38^{\circ} \mathrm{F}$., of plums from South Africa has improved their quality by reducing physiological injury.

The transport of fresh fruit from overseas is still often accompanied by excessive wastage, and the utmost care is and will always be required.

(4) There have been advances in the technique of preserving fruit by drying and in 
the packaging of dried fruit to reduce infestation. The production of dried fruit has decreased in Mediterranean countries, but has risen in Australia and South Africa.

Preservation by freezing has grown rapidly in the United States and to a less extent elsewhere. So far international trade in frozen food is small, but it may grow.

There have been considerable advances in the fruit-juice industry, and concentrated orange juice which was almost unknown before the war is now produced in the United States, Palestine and Rhodesia. So far there is no evidence that the supply of juices is reducing the demand for fresh fruit. In England the production of apple juice is increasing.

(5) About $90 \%$ of the world output of canned fruit comes from the United States. Before the war Britain imported some 200,000 tons of canned fruit, more than half of which came from there.

The total output of the principal Commonwealth countries was 170,000 tons, of which Malaya produced 48,000 . Production in Malaya has fallen but there have been substantial developments in South Africa, New 'Zealand and the West Indies.

(6) The supply of fruit is determined in part by marketing arrangements. Uniformity and attractiveness of packing are important factors in selling fruit. Fruit from overseas has in the past been generally more attractively packed than home-grown fruit. 'The National Mark scheme has not been re-introduced, but the establishment of large co-operative packing stations is resulting in supplies of home-grown apples and pears of high quality and attractively packed. Large-scale grading and packing are creating here, as elsewhere, the problem of disposing of large bulks of cull apples. Some are used for juice and cider. The possibility of drying some is being considered also.

(7) Fruit should be marketed at the correct state of ripeness. Increasing quantities of bananas and deciduous fruits are now being 'conditioned', i.e. stored at $65^{\circ} \mathrm{F}$. for a few days and, if need be, are treated with ethylene to ensure ripening, especially in winter months.

It seems probable that Britain's fruit supplies, which have now returned to the prewar pattern, are not likely to change radically in the near future but that certain tendencies are likely to continue. The present yearly consumption of $80 \mathrm{lb}$./head is probably higher than that of most European countries, but it is probable that most people would eat more fruit if they were not restrained by the cost.

This paper is published by permission of the Department of Scientific and Industrial Research.

REFERENCES

Heywood, R. H. (1950). Brit. F. Nutrit. 4, 53.

Hopkirk, C. S. M. (1950). Brit. J. Nutrit. 4, 57.

Robertson, J. G. (1950). Brit. $\mathcal{~}$. Nutrit. $4,49$.

van der Post, A. P. (1950). Brit. F. Nutrit. 4, 63. 